Creative Commons User License: CC BY-NC-ND

Abstracted by: EBSCOhost, Electronic Journals Service (EJS),

Google Scholar, Journal Seek, Scientific Commons,

Food and Agricultural Organization (FAO), CABI and Scopus

http://eoi.citefactor.org/10.11226/v23i4
Journal of Agricultural Extension

Vol. 24 (1) January, 2020

ISSN(e): 24086851; ISSN(Print); 1119944X

http://journal.aesonnigeria.org

http://www.ajol.info/index.php/jae

Email: editorinchief@aesonnigeria.org

\title{
Effects of Relative Pricing of Alternative Cooking Energy Sources on their Substitution between Rural and Urban Households in Enugu State, Nigeria
}

ttps://dx.doi.org/10.4314/jae.v24i1.8

\section{Onyekuru, Anthony NwaJesus}

Department of Agricultural Economics,

University of Nigeria

Email: anthony.onyekuru@unn.edu.ng

$+2347018311142$

\section{Eric Eboh}

Department of Agricultural Economics,

University of Nigeria

Email: eceboh@yahoo.com

$+234(0) 8036660475$

\section{Ume, Chukwuma Otum}

Department of Agricultural Economics,

University of Nigeria

Email: chukwuma.ume@unn.edu.ng $+2348032533956$

\section{Abstract}

This study investigated the effects of relative pricing of alternative cooking energy sources on their substitution. The study was conducted in Enugu State Nigeria using primary data collected from two hundred and four households from rural and urban areas of the state, using structured questionnaires. The information collected were pattern and levels of energy use, relative pricing of alternative energies and energy substitution pattern. Data were analyzed using multiple regression analysis and Chow test. Results show that the energy sources used in the rural areas are fuelwood (51.5\%) and kerosene (48.5), while those used in the urban areas are fuelwood (30.6\%), charcoal (31.6\%), kerosene (33.7\%) and liquefied petroleum gas (4.1\%). There was a relative cross inelastic nature of the energy sources. The price of fuel wood varied inversely and directly with quantities of kerosene demanded in the rural and urban areas, respectively, while the price of charcoal had an inverse relationship with the quantities of kerosene consumed in both urban and rural areas. In particular, policies geared towards subsidizng cost of kerosene and LPG and making them more readily available will lead to reduction in the use of fuelwoods and charcoal in both the rural and urban areas, thereby reducing excessive pressure on our forest and green house gas emission..

Key words: Energy substitution, energy pricing, forest conservation, 
Creative Commons User License: CC BY-NC-ND

Abstracted by: EBSCOhost, Electronic Journals Service (EJS),

Google Scholar, Journal Seek, Scientific Commons,

Food and Agricultural Organization (FAO), CABI and Scopus

http://eoi.citefactor.org/10.11226/v23i4
Journal of Agricultural Extension

Vol. 24 (1) January, 2020

ISSN(e): 24086851; ISSN(Print); $1119944 X$

http://journal.aesonnigeria.org

http://www.ajol.info/index.php/jae

Email: editorinchief@aesonnigeria.org

\section{Introduction}

Cooking energy accounts for $90 \%$ of all household energy consumption in developing countries (GIZ, 2019). It is estimated that by 2030, 2.52 billion people will still cook with biomass (Chukwuma, 2018a). In spite of the important role of biomass for cooking, it is considered 'dirty' and 'backward' and seldom associated with 'modern energy'. Mensah \& Adu (2015) and Kumar, Fujii, and Managi (2015) have investigated the various factors influencing households' cooking energy choice. Findings from their paper reveal significant transition from biomass energy use towards clean energy sources and this is been determined by factors such as relative prices of energy. However, despite the rising attention this economic and environmental matter has received, the study of how households react to changes in relative prices of cooking energy sources and of how relative prices affected the behavior of those agents is still relatively poorly understood.

Within each city, changing access to modern forms of energy is driven by fuel preference and it is constrained by various cost barriers (Ajah (2013). In view of low income level of the poor, the study observed that firewood is the dominant fuel for the poor, while firewood and charcoal use decline with higher household income. Kerosene is used by the poor mainly for lighting. Kerosene demand and consumption increase with income but they declines sharply as it is displaced by more desirable bottled gas (LPG) and electricity among the higher income group. It is stated that per capita consumption of energy is positively correlated with income and introducing income elasticity would help to access the energy-saving potential of demand and consumption much more accurately (Sunny, Alaezi, \& Chukwuma, 2018). Price of fuel encourages its adoption (demand) for home consumption. In this respect, fuel pricing plays a substantial role in determining the demand and consumption of a particular fuel source. Apart from cost of fuel, access to fuel has also been noticed as another crucial factor influencing fuel switching and demand; because kerosene shortage and long queues at the shops are given as the main reason for not using the fuel (De Saint Jean, Baurens, \& Bouallou, 2014).

Furthermore, in terms of energy substitution, De Saint Jean et. al., (2014) have viewed access to infrastructure as the major determinant of energy consumption pattern of households. Among households that are electrified and those that are not, there are significant differences regarding energy consumption pattern among households. When switched to electricity or kerosene stove, for instance, it is generally another fuel source that is used for cooking (Zoundi, 2017). This holds true at the household and community levels as electrification positively affects modern fuel use and negatively affects fuel wood consumption. Per capita expenditure, education and urbanization are also associated with fuel switching with larger households more likely to use multiple fuel sources (Zoundi, 2017). 
Creative Commons User License: CC BY-NC-ND

Abstracted by: EBSCOhost, Electronic Journals Service (EJS),

Google Scholar, Journal Seek, Scientific Commons,

Food and Agricultural Organization (FAO), CABI and Scopus

http://eoi.citefactor.org/10.11226/v23i4
Journal of Agricultural Extension

Vol. 24 (1) January, 2020

ISSN(e): 24086851; ISSN(Print); 1119944X

http://journal.aesonnigeria.org

http://www.ajol.info/index.php/jae

Email: editorinchief@aesonnigeria.org

The family average budget differs according to the type of fuel use and the city. A research conducted by Specht, Pinto, Albuquerque, Tabarelli, \& Melo, (2015) revealed that an increase in consumption and demand for fuel wood substitutes by households has been as a result of continuous deforestation leading to fuel wood shortage and steady fuel wood price increase. Within the Nigeria context, Chukwuma (2018a) observed that price of domestic energy is one of those factors that determine the sources of energy to households. In the study it is argued that although electricity production especially from hydro source and liquefied natural gas have increased over the years, it is still found that such commercial energy sources and equipment are generally unaffordable and inaccessible to the poor. On the other hand, Zoundi (2017) posited in their study of domestic energy supply and demand in rural India that the amount of fuelwood collected, labour input to fuelwood collection and amount of energy consumed are the variables of primary interest for the analysis of fuelwood collection and energy substitution.

The foregoing suggests that the underlying determinants of demand for cooking energy sources among rural and urban households are still unsettled issues requiring further study in order to establish a coherent scholarship in the area. Other things being equal, apart from the determinants as highlighted above, a change in the prices of close substitutes will also have effect on the individual cooking energy sources. The objective of this study therefore, is to examine the relationship between relative pricing of alternative cooking energy sources on their substitution. This is important for evaluating the efficacy of policies and programmes that promote clean cooking and sustainable energy for the developing nations like Nigeria. This is what this research set out to investigate.

\section{Methodology}

The study area is Enugu stae, south east Nigeria. It is made up of about 140 million people (NPC, 2006). The state is located within the tropical humid zone with derived Savannah vegetation at approximately $6^{\circ} 52^{\prime \prime}-7^{\circ} 53^{\prime \prime} \mathrm{E}$ and $6^{\circ} 38^{\prime \prime}-7^{\circ} 8^{\prime \prime} \mathrm{N}$. Data for the study were collected from Enugu state in South Eastern Nigeria. The state has a population of 3,257,298 (Igwe, Mode, Nnebedum, Okonkwo, \& Oha (2014). According to Igwe et. al (2014), the state is divided into three (3) major Agricultural zones viz: Enugu East, Enugu West and Enugu North.

A Multistage sampling procedure was adopted in this study. In the first stage one urban and one rural area (block) were purposively selected from each of the three agricultural zones, making it a total of 6 blocks. The second stage was the selection of cells from the blocks. With a list of political wards gotten from the ADP. From each of the 3 selected urban blocks two cells were randomly selected and from the rural blocks, two cells were randomly selected, giving a total of twelve cells in all. The last stage was the random selection of seventeen households from each of the selected wards giving a total of 204 respondents. The sample size was made up of all the households in each of 
Creative Commons User License: CC BY-NC-ND

Abstracted by: EBSCOhost, Electronic Journals Service (EJS),

Google Scholar, Journal Seek, Scientific Commons,

Food and Agricultural Organization (FAO), CABI and Scopus

http://eoi.citefactor.org/10.11226/v23i4
Journal of Agricultural Extension

Vol. 24 (1) January, 2020

ISSN(e): 24086851; ISSN(Print); 1119944X

http://journal.aesonnigeria.org

http://www.ajol.info/index.php/jae

Email: editorinchief@aesonnigeria.org

the wards. Multiple Regression analysis was employed to assess the determinnts of price elasticity, while Chow test was used used to assess the differences in determinants between the urban and rural households. Mathematically, regression model is expressed in implicit form as $Y=f\left(x_{1}, x_{2}, x_{3} \ldots x_{n}, u\right)$, or explicitly as $\mathrm{Y}=b_{0}+b_{1}+x_{1}+b_{2} x_{2}+b_{3} x_{3} \ldots \mathrm{B}_{n} X_{n}+U$. In the model, $\mathrm{Y}$ is the dependent- variable' $\mathrm{Xs}$ are independent- variables which are determined outside the models. They induce changes or explain the behaviour of dependent variables, hence form the basis for the prediction of the regressand. $b_{0}, b_{1}, b_{2}, b_{3} \ldots$ bn are the parameters which are the basic descriptive measures of population, elasticity or expected values while " $f$ " is the functional relationship which is the way the $\mathrm{x}_{1}$ are transformed to $\mathrm{Y}$. " $\mathrm{U}$ " is the error term, introduced into the model to take into account the influence of various errors like erratic (random) behaviour of humans. The dependent variables are defined thus:

$\mathrm{Y}_{\mathrm{k}}=$ quantity of energy source used

$\mathrm{O}_{\mathrm{c}}=$ Occupation of the respondents

Fs = Fmily Size

$P_{k}=$ Price of Energe source

In = Income level of the respondents

\section{Results and Discussion}

\section{Effects of Prices on Cooking Energy Substitution between Rural and Urban Households}

The effects of prices on cooking energy substitution in the rural, urban, and combination of rural and urban areas were determined using multiple regression analysis. The model for LPG was not run due to the few number of observations (4) in the data set, which was too small to run the model. Three functional forms, linear, semi-log and double log were fitted to determine the functional form with the best fit. It was observed that in all cases the double log functional form performed well and was selected as the lead equation in all the cases. In addition, it is the most preferred as the coefficient of each of the dependent variables gives their elasticity directly.

\section{Effect of Price on Substitution of Kerosene in Rural and Urban Areas}

Rsults of the effects of prices on the quantity of kerosene used in the rural areas shows. $\log Y_{k}=8.328-0.055 \log \mathrm{O}_{c}-0.02 \log \mathrm{Ed} .+0.54 \log \mathrm{Fs}-1.525 \log \mathrm{P}_{f}-1.671 \log \mathrm{P}_{\mathrm{k}}+0.004 \log \mathrm{In}$
(2.60)
$(-2.02)^{*}$
$(-0.98)$
$(6.84)^{\star * \star}(-1.77)^{\star}$
$(-5.20)^{\star \star *}$

$\mathrm{R}^{2}=0.9196, \mathrm{~F}-\mathrm{cal}=34.32, \mathrm{Prob}>\mathrm{F}=0.0000$.

The values in parenthesis are the t-values.

The $\mathrm{R}^{2}$ value (91.96) shows that the variables in the regression line explained about $92 \%$ of total variation in the quantity of kerosene used. The $F$ statistics value of 21.30 
Creative Commons User License: CC BY-NC-ND

Abstracted by: EBSCOhost, Electronic Journals Service (EJS),

Google Scholar, Journal Seek, Scientific Commons,

Food and Agricultural Organization (FAO), CABI and Scopus
Journal of Agricultural Extension

Vol. 24 (1) January, 2020

ISSN(e): 24086851; ISSN(Print); 1119944X

http://journal.aesonnigeria.org

http://www.ajol.info/index.php/jae

Email: editorinchief@aesonnigeria.org

with a $p$ - value of $0.0005 \%$ which is less than the level of significance of 0.01 , further gives extra confidence on the $\mathrm{R}^{2}$ value. The results show that occupation and price of fuelwood significantly influenced the quantity of kerosene used in the rural areas.

The result on the significance and sign of family size is consistent with a priori expectation as has been noted before. The price of kerosene agreed with a priori expectation by having an inverse relation with its quantity; price of fuel wood has an inverse relationship with the quantity of kerosene. This is a deviation from a priori expectation and could be as a result of the fact that in the face of astronomic kerosene price increase it also leads to the increase in the price of fuelwood leaving the households indifferent as to the type of energy to use in the short run, especially for households that are already used to cooking with kerosene and have no space for firewood burning. This is true with some well to do villagers who may also be civil servants and have no time to burn fuelwood. It takes a longer period for such household to make a significant shift to fuelwood burning. In addition, most of the respondents in the rural areas were more educated so are more prone to cooking with kerosene, thus, even level of education and occupation also varied inversely with quantity of kerosene used.

Results of the effects of prices on the quantity of kerosene used in urban areas shows: $\log Y_{k}=3.722-0.017 \log E d-0.001 \log F_{s}+0.009 \log P_{f}-0.049 \log P_{c}-0.007 \log P_{k}+2.420 \log \ln _{n}$ $(3.04)^{\star \star *}(-1.59) \quad(-0.05) \quad(0.19) \quad(-1.06) \quad(-6.45)^{\star * \star} \quad(3.79)^{\star * *}$

$\mathrm{R}^{2}=0.8405, \mathrm{~F}-\mathrm{cal}=8.82$, Prob $>\mathrm{F}=0.0000$.

The values in parenthesis are the t-values.

The value of the $R^{2}(0.8405)$ shows that the variables in the regression equation explain about $84 \%$ of variability in the quantity of kerosene consumed. The F statistics of 18.82 justifies the goodness of fit of the entire regression-line. From the results, price of kerosene and income were highly significant. Price of kerosene and fuel wood agreed with a-priori expectation by varying inversely and directly with quantity of kerosene respectively. Thus, an increase in the price of kerosene leads to a reduction in the quantity consumed ceteris paribus. The significance and sign of income are also intuitive as it is expected that as the income of the household increases, they are more disposed to use better fuel than those with lower income, ceteris paribus.

In comparison with the rural areas, the results show that the price of kerosene had the same effects on the quantity of kerosene used by having an inverse relationship with quantity in both areas. The price of fuel wood varied inversely and directly with quantity of kerosene in the rural and urban areas respectively, while the price of charcoal had an inverse relationship with the quantity of kerosene consumed in the urban areas. Thus it can be deduced that the high cost of kerosene is the cause of the shift by the rural dwellers to the use of more fuelwood, while the urban dwellers intensified their use of 
Creative Commons User License: CC BY-NC-ND

Abstracted by: EBSCOhost, Electronic Journals Service (EJS),

Google Scholar, Journal Seek, Scientific Commons,

Food and Agricultural Organization (FAO), CABI and Scopus

http://eoi.citefactor.org/10.11226/v23i4
Journal of Agricultural Extension

Vol. 24 (1) January, 2020

ISSN(e): 24086851; ISSN(Print); 1119944X

http://journal.aesonnigeria.org

http://www.ajol.info/index.php/jae

Email: editorinchief@aesonnigeria.org

charcoal. This may be due to the fact that the price increase in fuelwood and charcoal may appear insignificant in both cases compared with the price increase in kerosene.

Result of the effects of prices on the substitution of kerosene in rural and urban areas shows:

$\log Y_{k}=6.189-0.053 \log O_{c}-0.029 \log E_{d}+0.338 \log F s-0.717 \log P f-0.958 \log P_{c}-1.641 \log P_{k}+0.180 \operatorname{long} I_{n}$
$(2.50)^{\star *} \quad(-1.52) \quad(-0.57)$
$(4.59)^{* \star *} \quad(-0.98)$
$(-0.57)$
$(-7.15)^{\star * *}$
$(2.71)^{\star \star \star}$
$R^{2}=0.8168, f-c a l=31.77$, Prob $>F=0.0000$.

The values in parentheses are the t-values

The values of $R^{2}(0.8168)$ indicate that the variables in the regression line explain about $82 \%$ of variability in the quantity of kerosene consumed by households. The F-statistics value of 31.77 shows the goodness of fit of the entire regression line. From the results family size, price of kerosene and income were highly significant,indicating that they highly affect the consumption of kerosene. All the three agreed with a priori expectation with respect to the direction of changes.

This result shows the unity in behaviour of all the households regardless of whether they are in the rural or urban areas. Kerosene price hike has a universal effect in Nigeria, as virtually all the households use it for cooking, thus any change in the price of kerosene posses a great threat to the Nigerian households. The positive relationship beteen family size, income and quantity of kerosene used also agree with the economic theory - the higher the income the higher the probability of the use of a convenient fuel (kerosene in the case of Nigeria) and the higher the family size the higher the quantity of energy used ceteris paribus.

\section{Effect of Price on Substitution of Fuelwood in Rural and Urban Areas}

Result of the effects of prices on the quantity of fuel wood consumed by households in the rural areas shows.

$\log Y_{f}=1.97+0.0914 \log \mathrm{O}_{c}+0.001 \log E_{d}+0.046 \log F s+0.043 \log _{f}+0.002 \log P_{k}+\left.3.040 \log \right|_{n}$
$(2.42)^{* *} \quad(1.10) \quad(0.15)$
$(3.51)^{\star * \star}$
(0.88)
(0.84)

$R^{2}=0.4717, F-c a l=3.32$, Prob $>F=0.0117$. The values in parenthesis are the t-values.

The value of the $R^{2}(47 \%)$ is lower than average, showing that the variables in the regression model explain only about $47 \%$ of variability in the quantity of fuel wood used in the rural areas. This is reflected in the significance of only family size among all the variables, which had a positive significant relationship at $P \leq 0.01$ to quantity of fuel wood. This was in agreement with finding of Lin \& Xie (2014) and Das, De Groote, \& Behera (2014).

The low $R^{2}$ could not be far from the that the use of fuel wood is highly influenced by some qualitative socio-cultural factors in the rural areas like the taste it gives to food, speed of cooking, its preferences in cooking large quantity of food in ceremonies and other traditional beliefs. Most elders in the rural areas can differentiate between any 
Creative Commons User License: CC BY-NC-ND

Abstracted by: EBSCOhost, Electronic Journals Service (EJS),

Google Scholar, Journal Seek, Scientific Commons,

Food and Agricultural Organization (FAO), CABI and Scopus

http://eoi.citefactor.org/10.11226/v23i4
Journal of Agricultural Extension

Vol. 24 (1) January, 2020

ISSN(e): 24086851; ISSN(Print); 1119944X

http://journal.aesonnigeria.org

http://www.ajol.info/index.php/jae

Email: editorinchief@aesonnigeria.org

dish cooked with fuelwood and those cooked with other energy sources just by tasting the food and therefore never eat any food not cooked with fuelwood. These factors were not captured quantitatively in the regression model and this may also have accounted for the non-significance of kerosene price in the model and its positive sign. Thus, the use of fuelwood in the rural areas does not necessarily depend on its price as either it is an energy of last resort or the households fetch it from their farms and as been said before, it is not priced and unaccounted for in their energy budget.

The F-cal value of 3.32 shows the goodness of fit of the regression line. For effects of prices on quantity of fuel wood, the positive sign of fuel wood's own price deviated from a-priori expectation, this could also be due to the reasons already explained in previous sections, that is, as a result of the very high cost of kerosene and its scarcity, families could not afford to switch over to kerosene in the rural areas in the face of little change in the price of fuel wood which was cheaper, thus they tend to consume more. This reason also explains the positive signs of occupation and education. The other variables: price of kerosene and household size have positive signs, thereby agreeing with a priori expectations.

Result of the effects of prices on the quantities of fuel wood consumed by urban households shows.

$\log \mathrm{Y}_{f}=-5.016+0.015 \log \mathrm{O}_{c}-0.002 \log \mathrm{E}_{d}-0.054 \log \mathrm{F}_{\mathrm{s}^{-}} 0.075 \log \mathrm{P}_{f}+1.628 \log \mathrm{Pc}_{\mathrm{c}}+3.300 \log \mathrm{P}_{\mathrm{k}}-0.109 \log \mathrm{l}_{\mathrm{n}}$
$(-0.79) \quad(0.40)$
$(-0.04)$
$(-0.37) \quad(-0.04)$
(0.46)
$(5.83)^{\star \star \star}$
$(-0.85)$
$R^{2}=0.8235, F_{-c a l}=12.26$, Prob $>F=0.0000$

The results $\left(R^{2}=0.8236\right)$ show that the variables in the model explain about $82 \%$ of the variations in the quantity of fuel wood used in urban households. The value of the F-cal (12.26) confirms the goodness of fit of the regression line.

The price of kerosene was highly significant, positively related to the quantity of fuelwood and has a very high marginal effects on the quantity of fuel wood consumed. This result is consistent with a priori expectation and kerosene and fuelwood are substitutes and the price fluctuation of kerosene is a major determinant in the use of fuelwood among the urban households. The other variables, price of fuel wood and price of charcoal had negative and positive signs respectively thereby agreeing with $a$ priori expectation while income had negative sign also agreeing with a priori expectations, though they are not statistically significant.

A look at the demand of fuelwood in both areas shows that the price of fuel wood agreed with a priori expectation in the urban area by having a negative sign, while it was otherwise in the rural areas, the reason may be that the rural households find it difficult to substitute kerosene for fuelwood because of its cost and scarcity in the rural areas. Thus have no other choice than to use more fuelwood regardless of the cost. As for 
Creative Commons User License: CC BY-NC-ND

Abstracted by: EBSCOhost, Electronic Journals Service (EJS),

Google Scholar, Journal Seek, Scientific Commons,

Food and Agricultural Organization (FAO), CABI and Scopus

http://eoi.citefactor.org/10.11226/v23i4
Journal of Agricultural Extension

Vol. 24 (1) January, 2020

ISSN(e): 24086851; ISSN(Print); 1119944X

http://journal.aesonnigeria.org

http://www.ajol.info/index.php/jae

Email: editorinchief@aesonnigeria.org

price of kerosene, it agreed with a-priori expectation by having positive sign in both areas.

Results of the effects of prices on the quantity of fuel wood consumed by both urban and rural households shows

$\log Y_{f}=66.671 \log O_{c}-1.348 \log E_{d}+15.770 \log F_{s}+15.503 \log P_{f}-6946 \log P_{c}+5.126 \log P_{k}+0.0004 \log l_{n}$
$(1.75)^{*}$
$(-0.44)$
$(2.93)^{\star \star \star *}$
$(0.79)$
$(-0.19)$
$(5.77)^{\star \star \star}$
(1.56)

$\mathrm{R}^{2}=0.5224, \mathrm{~F}-\mathrm{cal}=8.48$, Prob $>\mathrm{F}=0.0000$

The value of $R^{2}(0.5524)$ shows that about $55 \%$ of variation in the quantity of fuel wood consumed is explained by the variables in the model. The value of F-cal (8.48) means that the regression line is statistically adequate to explain the observed variation. The results show that family size and price of kerosene were highly significant and positively related to quantity of fuel wood thus they agreed with a priori expectation. Thus the higher the duo the higher the quantity of fuelwood consumed, this is also in line with earlier findings above. Thus, the results are following the same trend in agreement with economic theory regarding expectation about the effect of the variables on the demand of the energy sources. Prices of fuel wood had positive relationship to quantity showing that it did not agree with a priori expectations. In the case of price of fuelwood, it has been earlier explained that it may be due to the households' inability to substitute it with the costly kerosene in the short run.

\section{Disparity in Determinants of Demand for Kerosene between Urban and Rural Households}

To identify whether the determinants of the demand for kerosene in the rural areas differ significantly from the urban areas and if the determinants of the demand for fuel wood in the rural areas differ significantly from the urban areas, Chow test of equality was performed. The result is presented in Table 1.

Table 1: Chow test of differences between the determinants of the demand for kerosene and fuelwood in the rural and urban areas

\begin{tabular}{ll}
\hline Variables tested & F Statistics \\
\hline The demand for kerosene in the rural and & $4.00^{*}$ \\
urban areas & \\
$\begin{array}{l}\text { The demand for fuelwood in the rural and } \\
\text { urban areas }\end{array}$ & $3.05^{*}$ \\
\hline${ }^{*} \mathrm{P} \leq 0.05$ &
\end{tabular}

${ }^{*} \mathrm{P} \leq 0.05$

The result of the chow test of differences between the determinants of the demand for kerosene and fuelwood in the rural and urban areas produced an $F$ - statistics significant at 0.05 confidence Ivel for both variables tested. This result implies that the determinats of demand for kerosene and fuelwood in the rural areas differ from 
Creative Commons User License: CC BY-NC-ND

Abstracted by: EBSCOhost, Electronic Journals Service (EJS),

Google Scholar, Journal Seek, Scientific Commons,

Food and Agricultural Organization (FAO), CABI and Scopus

http://eoi.citefactor.org/10.11226/v23i4
Journal of Agricultural Extension

Vol. 24 (1) January, 2020

ISSN(e): 24086851; ISSN(Print); 1119944X

http://journal.aesonnigeria.org

http://www.ajol.info/index.php/jae

Email: editorinchief@aesonnigeria.org

dterminants of demand among households in the urban areas. This implies that a general consideration in policy formuation will be counterproductive, hence, different considerations should be taken in addreesing ways of implementing energy substttution in the area.

\section{Conclusion and Recommendation}

There is a relative inelastic nature of energy sources at both the rural and urban areas. Whereas a simple subsidy of clean energy sources will help reduce the demand for unclean energy sources, efforts must also be made to consider the socioeconomic drivers that were found to significantly influence demand for unclean energy sources. Care should be taken in policy formulation such that policies should not be allencompassing for both the rural and urban areas but should consider the individual socioeconomic peculiarities across these areas.

\section{References}

Ajah Julius , (2013). Households' access and preference to cooking fuels in Abuja, Nigeria. Journal of Environmental Science and Technology, 6: 91-98.

Chukwuma Ume (2018a). Tragedy of the commons and economics of deforestation in Nigeria. Journal of Biodiversity Management \& Forestry, 06(01), 1-7. https://doi.org/10.4172/2327$\underline{4417.1000175}$

Chukwuma Ume. (2018b). Critical Perspective on climate change adaptation among farmers in developing nations: Unpacking divergent approaches. Modern Concepts \& Developments in Agronomy, 1(1), 1-6. https://doi.org/10.31031/mcda.2017.01.000504

De Saint Jean, M., Baurens, P., \& Bouallou, C. (2014). Parametric study of an efficient renewable power-to-substitute-natural-gas process including high-temperature steam electrolysis. international journal of hydrogen energy, 39(30), 17024-17039.

Energy Commission of Nigeria (ECN) (2012). Renewable Energy Masterplan, 2nd ed.Energy Commission of Nigeria: Abuja, Nigeria, 2012

GIZ (2018). Productive uses of energy (PUE) and the role of civil society organizations. Coalition Webinar Series 2019. Retrieved 22nd April, 2019 from https://energypedia.info/wiki/Facts on Cooking Energy

Igwe, O., Mode, W., Nnebedum, O., Okonkwo, I., \& Oha, I. (2014). The analysis of rainfallinduced slope failures at Iva Valley area of Enugu State, Nigeria. Environmental earth sciences, 71(5), 2465-2480.

Kumar, S., Fujii, H., \& Managi, S. (2015). Substitute or complement? Assessing renewable and nonrenewable energy in OECD countries. Applied Economics, 47(14), 1438-1459.. 
Creative Commons User License: CC BY-NC-ND

Abstracted by: EBSCOhost, Electronic Journals Service (EJS),

Google Scholar, Journal Seek, Scientific Commons,

Food and Agricultural Organization (FAO), CABI and Scopus

http://eoi.citefactor.org/10.11226/v23i4
Journal of Agricultural Extension

Vol. 24 (1) January, 2020

ISSN(e): 24086851; ISSN(Print); $1119944 X$

http://journal.aesonnigeria.org

http://www.ajol.info/index.php/jae

Email: editorinchief@aesonnigeria.org

Das, S., De Groote, H., \& Behera, B. (2014). Determinants of household energy use in Bhutan. Energy, 69, 661-672.

Lin, B., \& Xie, C. (2014). Energy substitution effect on transport industry of China-based on trans-log production function. Energy, 67, 213-222.

Mensah, J. T., \& Adu, G. (2015). An empirical analysis of household energy choice in Ghana. Renewable and Sustainable Energy Reviews, 51, 1402-1411.

Specht, M. J., Pinto, S. R. R., Albuquerque, U. P., Tabarelli, M., \& Melo, F. P. (2015). Burning biodiversity: Fuelwood harvesting causes forest degradation in human-dominated tropical landscapes. Global Ecology and Conservation, 3, 200-209.

Sunny. U. C, Alaezi Kingsley, Chukwuma Ume. (2018). Climate change vulnerability analysis of smallholder farmers in Enugu state Nigeria: Gender sensitive approach. Journal of Aridland Agriculture, 01-06. https://doi.org/10.25081/jaa.2018.v4.3374

United Nations Development Programme, UNDP (2012). Sustainable energy, environment and energy: focus area; Accessed on 22/03/17 from http://www.undp.org/content/undp/en/home/ourwork/environmentandenergy/foc sareas/sustainable-energy.html

Zoundi, Z. (2017). CO2 emissions, renewable energy and the Environmental Kuznets Curve, a panel cointegration approach. Renewable and Sustainable Energy Reviews, 72, 10671075.

Zha, D., \& Ding, N. (2014). Elasticities of substitution between energy and non-energy inputs in China power sector. Economic Modelling, 38, 564-571. 